Piotr Prósinowski

Uniwersytet Gdański

\title{
Sumienie graczy: podejmowanie decyzji w fabularnych grach komputerowych w kontekście socjalizacji i wrażliwości społecznej
}

W świecie, w którym następuje gwałtowny rozwój technologii informatycznych, należy przyjrzeć się problemom przez niego generowanym. Pedagodzy nie tylko powinni umieć dostrzegać to, co nowe, ale spróbować podejść do tego badawczo.

Coraz więcej dzieci gra w gry komputerowe. Ich inicjacja na tym polu dokonuje się szybciej niż kiedyś. Granie jest również istotną aktywnością młodzieży i dorosłych. Warto postawić sobie pytanie o to, czy przeklinać ducha naszych czasów, czy lepiej podjąć wysiłek zbadania potencjalnych korzyści, które może przynieść ta forma rozrywki.

Gry komputerowe w świadomości pedagogów wiążą się ze złem, z metaforycznym demonem kuszącym zwłaszcza uczniów i namawiającym ich do porzucenia nauki na korzyść pustej, nierozwijającej intelektualnie zabawy. W tym kontekście współczesny postęp technologiczny budzi niepokój. Zupełnie tak, jakby to, co nowe, musiało wiązać się z lękiem i zagrożeniem.

Moim zdaniem technologiczna nowość jest wyposażona w spory edukacyjny potencjał, dzięki któremu powstają nowe możliwości nauczania. Na różnego rodzaju zajęciach są wykorzystywane aplikacje uatrakcyjniające procesy edukacyjne, natomiast $\mathrm{w}$ codzienności pojawiają się narzędzia inkulturacji w postaci gier wideo, które nie tylko wdrażają graczy w kulturę XXI wieku, ale także opowiadają historie często wymagające analizy ze strony odbiorcy. Gry komputerowe przyczyniają się do rozwoju kultury i nauki. Mechanizm gamifikacji (zwanej także grywalizacją) wykorzystuje mechanikę gier do zachęcania ludzi, aby robili rzeczy, na które zwyczajnie nie mają ochoty lub nie wiedzą, że mogą zrobić je inaczej poprzez uatrakcyjnienie, wsparcie motywacji wewnętrznej oraz budzenie kreatywności. Systemy znane z gier można wykorzystać do usprawnienia pracy nad projektami oraz edukacją, ale sprawdzają się też w działaniach bardziej bezpośrednich - jako socjalizacyjne przekazy lub narzędzia uwrażliwiania na współczesne problemy społeczne.

W niniejszym tekście postaram się przyjrzeć potencjałowi fabularnych gier komputerowych $\mathrm{w}$ kontekście socjalizacji, uwrażliwienia oraz edukacji; zaprezentuję wyniki badań wstępnych, które mają za zadanie przybliżyć pedagogom 
ich możliwe oddziaływanie na graczy oraz przynajmniej częściowo ująć relacje pomiędzy graczem a fabularną grą komputerową. Badania zostały przeprowadzone przeze mnie na próbie 171 osób w różnym wieku i bazowały na krótkiej ankiecie internetowej dotyczącej podejmowania decyzji w fabularnych grach komputerowych. Ankieta składała się z pytań zarówno zamkniętych, jak i otwartych, których zadaniem było pogłębienie odpowiedzi, dodanie wartości w postaci konkretnych przykładów gier, sytuacji oraz przemyśleń, a rozprowadzone zostały dzięki wsparciu portali społecznościowych oraz forów dyskusyjnych. Badanie przeprowadzono $\mathrm{w}$ języku polskim, toteż pula ankietowanych ogranicza się głównie do graczy narodowości polskiej.

Zanim zostaną zaprezentowane wyniki oraz moje rozważania nad wspomnianymi kwestiami, należy nadmienić, że celem artykułu nie jest oczyszczenie fabularnych gier komputerowych ze wszystkich zarzutów; nie chodzi tutaj o sakralizację tego rodzaju tekstu kulturowego, a raczej próbę ponownego spojrzenia na ten typ gier jako na nowe zjawisko ze swoimi możliwościami oraz niemożliwościami.

\section{Wiek rozwoju i badania komputerowych gier fabularnych}

Badania gier komputerowych są stosunkowo młode, zwłaszcza w Polsce. Temat gier był marginalizowany - szczególnie w pedagogice - i często widziany jako przeszkoda na drodze do skutecznego uczenia się, choć pewien wyłom w tej kwestii niesie dziedzina zwana pedagogiką gier komputerowych. Przełomowa na gruncie badań okazała się praca Jerzego Zygmunta Szeji zatytułowana Gry fabularne - nowe zjawisko kultury wspótczesnej (Szeja 2004). W swojej książce autor zauważa, że gry komputerowe - tuż obok narracyjnych gier fabularnych (role-playing game) - są nowym zjawiskiem kultury współczesnej. Już na samym początku nazywa gry komputerowe tekstem kultury (Szeja 2004: 8), co jest istotnym spostrzeżeniem oraz próbą odejścia od zinfantylizowanego poglądu na wszelkiego rodzaju gry. Niestety, powszechnie uważa się, że gry (czy komputerowe, czy planszowe lub towarzyskie) są domeną dzieci. Jeżeli nawet wiąże się je z dorosły$\mathrm{mi}$, to z tymi, którym powaga jest obca. Poprzez nazwanie gry tekstem kultury przełamuje się wizja „niepoważnego produktu”. Szeja nie podchodzi do tematu w sposób oderwany od rynku - wspomina tytuły, podaje przykłady. Praca przestaje mieć wymiar całkowicie abstrakcyjny, ponieważ autor postawił most - każdy może sprawdzić konkretny produkt, wie czego i gdzie ma szukać, w ten sposób zachęcając badaczy do zajęcia się tematyką gier.

Po Szeji pojawili się nowi, zazwyczaj młodzi badacze gier komputerowych. Widać pewną tendencję zajmowania się grami typu MMORPG (Massively multiplayer online role-playing game) pozwalającymi graczom na wspólne rozgrywki w czasie rzeczywistym w rozbudowanym świecie podzielonym na regiony. Gry te budzą duże zainteresowanie, ponieważ w dużej mierze są łatwo dostępne i darmowe - chociaż istnieją oczywiście też znane gry MMORPG wymagające płatnego abonamentu. Do popularnych MMO można zaliczyć: World of Warcraft, EverQuest, Rappelz, League of Legends (popularny LoL, który bardziej wiąże się z gatunkiem multiplayer online battle arena, polegającym na prowadzeniu bitew online) 
czy wydany w 2013 roku Neverwinter. Znaczna liczba badaczy społecznych skupia się na grach typu MMO dlatego, że uczestniczenie w rozgrywkach tego gatunku wymusza interakcje z innymi osobami; gry te zostały stworzone specjalnie z myślą o wspólnych rozgrywkach graczy z całego świata. Przykładem badań gier MMO oraz ogólnie gier sieciowych jest chociażby Wirtualny plac zabaw. Gry sieciowe i przemiany kultury współczesnej Mirosława Filiciaka (2006) czy teksty młodych badaczy, na przykład Komputerowe gry fabularne - pogranicze światów rzeczywistego i wirtualnego Dominika Porczyńskiego (Porczyński 2013) lub Wirtualny Teatr. Koncepcje Ervinga Goffmana w świecie gier sieciowych Pawła Olejniczaka (2012).

Odważę się stwierdzić, że pomimo rosnącego zainteresowania tematyką gier komputerowych, brakuje w naukach społecznych - zwłaszcza w pedagogice - analizy gier fabularnych, spojrzenia na nie jak na tekst kulturowy obrazujący pewne potrzeby społeczne, wizje, a także wyobrażenia deweloperów na temat dobrej gry komputerowej. Autorzy gier przekazują nam w swoich produkcjach konstrukty, z którymi gracze stykają się niemalże codziennie. Raport Game Industry Trends 2014 (GIT: Kids 2014) wykazuje, że według rodziców ich podopieczni przy grach (w ciągu tygodnia) spędzają: 9\% dzieci mniej niż godzinę, 45\% dzieci od jednej do pięciu godzin, 30\% dzieci od sześciu do dziesięciu godzin, 10\% dzieci od jedenastu do piętnastu godzin, 6\% dzieci powyżej szesnastu godzin. Wyniki pokazują, jak dużo czasu dzieci (a pamiętajmy, że także dorośli grają w gry komputerowe) spędzają na obcowaniu z tego typu produktami. Skoro gry polegają na odbiorze wizualnym, tekstowym konstruktów oraz na interakcji, przekazywane zostają treści, a ogólna ich zawartość w dużej mierze zależy od przekonań autorów. Gry - tak jak literatura - przekazują konstrukty, opowiadają o nich, tworzą fantazmaty. Trudno więc nie stwierdzić, że skoro gry są fuzją przekonań twórców o ludziach (tworzą aktorów gier na podstawie swoich wyobrażeń o ludzkich zachowaniach, lękach, pragnieniach, poglądach, mniejszościach itd.) oraz wizją odbiorcy (deweloperzy zawsze mają przed sobą obraz tego, do kogo gra jest skierowana), przekazywane zostają pewne treści kulturowe. Jakiego rodzaju treści - czy będą to na przykład stereotypy, czy myśli emancypacyjne, czy wprost przeciwne - wszystko zależy od twórców konkretnego tytułu. Czy już samo to nie jest powodem do analizy zawartości gier pod kątem konstruktów w nich występujących?

Przechodząc dalej, w kierunku głównego tematu tegoż tekstu, sposobem na immersyjne zaangażowanie gracza, na przekazanie myśli poprzez grę, jest stawianie w niej problemów - za pomocą fabuły, postaci, wydarzeń oraz tego, co pomiędzy tymi elementami gier zachodzi. Użytkownik rozwiązuje problemy poprzez podejmowanie decyzji - czy to w postaci dialogów, elementów strategicznych (które to można odnaleźć także w grach typu role-playing game), czy samych akcji gracza (na przykład kogo zabić, kogo oszczędzić lub uratować). Dokonywanie wyborów jest kluczowe i to właśnie ten element jest kwintesencją interakcji odbiorca-gra.

Bazując właśnie na tejże myśli, przeprowadziłem badanie mające na celu określenie stosunku graczy wobec decyzji podejmowanych w grach komputerowych. Czy decyzje są widziane jako niezbędne? Czym kierują się gracze? W jaki sposób dochodzi do ich zagłębienia w świat wirtualny? Jak do tego wszystkiego ma się sumienie oraz czy pełni ono istotną funkcję, gdy mamy do czynienia $\mathrm{z}$ tworem wirtualnym jakim jest gra komputerowa? 


\section{Podejmowanie wirtualnych decyzji - upragnione wyzwanie}

Niezwykle istotne pytanie, które warto postawić, dotyczy stosunku graczy do decyzji w grach. Za cel postawiłem sobie wyzbycie się własnej opinii i zapytanie graczy, czy właściwie sami są zadowoleni z takiej możliwości oraz czy lubią dokonywać w nich wyborów. Postanowiłem podjąć próbę rozbicia jednego pytania na dwa osobne, lecz stoi za tym pewien powód. Gracze mogą sobie cenić możliwość podejmowania decyzji w grach, ale nie wolno wykluczyć tego, że sam proces decydowania uznają za trudny, frustrujący czy na swój sposób męczący. Okazało się jednak, że odpowiedzi statystycznie pokryły się idealnie.

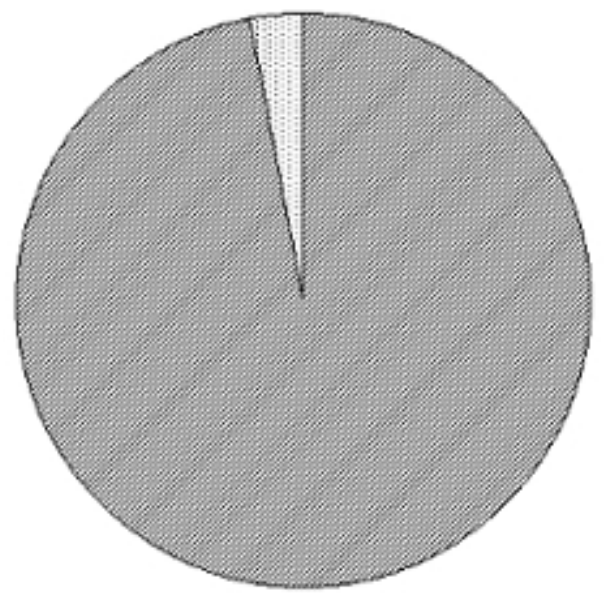

gracze zadowoleni z możliwości decydowania/lubiący ten aspekt gier $-97 \%$

gracze niezadowoleni z możliwości decydowania/nielubiący tego aspektu gier $-3 \%$

Wykres 1. Liczba graczy zadowolonych z możliwości podejmowania decyzji w grach oraz lubiących ten aspekt fabularnych gier komputerowych

Co ciekawe, nie każda osoba zadowolona z możliwości podejmowania decyzji w grach deklarowała, że to lubi, jednakże głosy ostatecznie wyrównały się.

Jak widać, znacząca większość graczy docenia możliwość decydowania w fabularnych grach komputerowych. Czy jest to istotna wiadomość? Owszem. Dokonywanie wyboru zawsze należało do ważnych aktywności. Tutaj pragnę nawiązać do tekstu Zygmunta Baumana i Tima Maya:

W życiu codziennym nigdy nie zabraknie problemów. Niektóre, pojawiając się w miarę regularnie, mogą nas nie kłopotać nadmiernie, podczas gdy inne mogą powodować gwałtowną zmianę sytuacji i zmuszać do dłuższego i głębszego namysłu. Są to problemy, którym zazwyczaj nie poświęcamy wiele uwagi, które jednak mają znaczenie dla tego, kim jesteśmy i jak pojmujemy otaczający nas świat. Czasami ów głębszy namysł prowadzi do pytania, dlaczego do czegoś doszło (Bauman, May 2004: 88).

Tak jak w życiu codziennym, także w grach komputerowych podejmowanie decyzji niesie za sobą znaczenie. W wielu grach fabularnych gracze są stawiani przed wyborami trudnymi, o niejasnych rezultatach. Przed ich dokonaniem muszą się zastanowić, jako że z decyzjami związane są konsekwencje - także takie, 
które nie są widoczne od razu po wyborze. W niektórych przypadkach skutek decyzji może ujawnić się dopiero pod sam koniec rozgrywki lub nawet w kontynuacjach gry (jak na przykład w serii Mass Effect wydanej przez firmę BioWare - decyzje podjęte w części pierwszej gry mają wpływ nawet na wydarzenia z części trzeciej). Jakie niesie to za sobą konsekwencje? Niemalże usunięta zostaje możliwość wczytania stanu gry i zmiany obranej ścieżki. Oczywiście jest to dopuszczalne w przypadku mniej istotnych zadań, lecz mimo wszystko gracze zostają zmuszeni do wzięcia odpowiedzialności za te istotne i często najtrudniejsze wybory. Nie ułatwia tego immersyjność gier komputerowych rozumiana tutaj jako wrażenie przenikania do innej rzeczywistości - w tym przypadku rzeczywistości świata gry (Filiciak 2006: 62). Immersja polega na czasowym zatrzymaniu niewiary; zanurzeniu podmiotu w świat fikcyjny w takim stopniu, że zdaje się on bardziej prawdziwy niż ten realny. Także decyzje zdają się istotniejsze - wiemy, że obcujemy z grą, jednak wzrasta poczucie odpowiedzialności za świat wirtualny, który kształtujemy naszymi wyborami. Warunkami immersyjności są interakcyjność produktu (gracz musi mieć wpływ na świat fikcji), spójności rzeczywistości prezentowanej w produkcie, a oczekiwania odbiorcy wobec produktu muszą być zgodne z jej konwencjami (Filiciak 2006: 63). Immersję łatwo wyjaśnić na przykładzie wciągającej książki - czytając ją, zgadzamy się na jej konwencję, formę; wchodzimy z nią w interakcje, bo podczas lektury wyobrażamy sobie postacie, zdarzenia, scenerię - przestajemy być jedynie biernymi odbiorcami, ale poprzez wyobraźnię tworzymy uniwersum prezentowane w dziele; musimy wierzyć w wiarygodność aktorów powieści, fabuły i innych elementów - odkrycie niekonsekwencji czy błędów logicznych, płaskiej psychologii postaci sprawia, że zostajemy wybici ze świata fikcji, niedowierzamy mu.

Czy rodzaj podejmowanych decyzji ma znaczenie? Owszem, jako że nadanie im powagi, odpowiednie ich nazwanie dzięki immersyjności jeszcze bardziej zaczyna się liczyć, a poprzez charakter decyzji może dojść do uwrażliwienia idiosynkratycznego - charakterystycznego dla konkretnej osoby (tutaj gracza) odczuwania w ten, a nie inny sposób, budującego osobowość gracza oraz to, co go uosabia (metaforycznie oraz dosłownie, przemyślenia i sądy odbiorcy gry oraz wizja wirtualnego odpowiednika gracza - awatara - w sensie budowania jego osobowości w grze na podstawie czynów i decyzji). Gry mogą stawiać graczy w sytuacjach niejasnych - można by stwierdzić, że zupełnie tak samo jak życie, wymuszając zastanowienie i podjęcie decyzji - tej jednej, charakterystycznej dla konkretnego człowieka. Oczywiście liczba decyzji w grach jest ograniczona, ale nierzadko zróżnicowana. Gdy na postawiony problem możemy odpowiedzieć na trzy czy cztery sposoby, wiedząc, że nasz wybór będzie miał wpływ na rozgrywkę, musimy zareagować. Gracz może to zrobić w parę sekund, ale często zajmuje to więcej czasu. Staje się swojego rodzaju sędzią decydującym o tym, jak rozwinie się historia. Tutaj można nawiązać do teorii Philipa Zimbardo opisanej w książce Efekt Lucyfera. Dlaczego dobrzy ludzie czyniq zło? (Zimbardo 2008), znanej także fanom filmów psychologicznych dzięki filmowi Das Experiment (pl. Eksperyment). Teoria zakłada, że poprzez stworzenie odpowiedniego środowiska/warunków, człowiek przybierający rolę wchodzi w nią niemalże całkowicie, do takiego stopnia, że ludzie uznawani za dobrych zaczynają zachowywać się w sposób zły, nikczemny, bezwzględny. Jak odnosi się to do gier komputerowych? Przykładem 
może być Dragon Age: Inquisition wydana w listopadzie 2014 roku. Wcielamy się tu w postać (kobietę lub mężczyznę), która jako jedyna przeżyła atak istot zła wydostających się z nowo powstałej szczeliny do świata żywych - za inwazję zostaje obarczony winą główny bohater. Po względnym oczyszczeniu z zarzutów wstępujemy w szeregi Inkwizycji, a później stajemy na jej czele. Będąc przywódcą, nie tylko odpowiadamy za wszystkie decyzje strategiczne, sojusze, walkę ze złem, ale także stajemy się swojego rodzaju sędzią. W związku z tym mamy obowiązek wysłuchać historii postaci, zarzutów i zeznań. Oczywiście naszym zadaniem jest także wydać wyrok (jeden z kilku dostępnych). Sama wysoka interakcyjność gry zapewnia immersję, wczuwamy się postać (lub wręcz przeciwnie - stawiamy siebie na jej miejscu, zamiast przyjmować sugerowaną przez grę rolę). Jednocześnie gra, zapewniając takie, a nie inne środowisko, każe nam słuchać i decydować. Gracz, będąc pod wpływem immersji, przyjmuje rolę i musi decydować, nie ma możliwości przyjęcia biernej postawy. Tak jak w teorii Zimbardo, gracz rzucony zostaje w ustaloną z góry sytuację, w której prowokowane są pewne zachowania. Musi zostać sędzią i przemyśleć to, co się dzieje wokół niego. Kończąc rozgrywkę, wychodzi z roli, ale doświadczenie i pamięć pozostają - tak jak wrażenia, wnioski i przemyślenia.

Gry, tak jak literatura, mają możliwość pozostawienia czegoś, co tutaj nazwę „wrażeniem”. Wrażenie jest jak pamięć, ale rozbudza człowieka w określony sposób. Poprzez fikcyjne zdarzenia oferowane są doświadczenia rozwijające - doświadczenia podejmowania decyzji, dawania poczucia realności oraz kompetencji sprawczej. A więc paradoksalnie osoba obcująca z fikcją - czy to w postaci gier, książek, czy innych interaktywnych produktów kultury - dzięki odwołaniu się do niej zdobywa elementy kompetencji realnych, składających się na to, co tworzy człowieka. Upraszczając teorię, człowiek przez obcowanie z fikcyjnym uniwersum odbywa "trening kulturowy". Tutaj chciałbym nawiązać do obserwacji badacza innego fragmentu kultury (dokładnie rzecz ujmując, horroru literackiego) - Michała Kruszelnickiego:

Zarówno widz tragedii, jak i czytelnik horroru świadomie pragną obcować z bohaterami zagrożonymi, cierpiącymi, wpadającymi w różne kłopoty, z którymi sami odbiorcy nie chcieliby mieć nic do czynienia (Kruszelnicki 2010: 70).

Nawiązuję do tego cytatu nie bez powodu. Tak jak w przypadku horroru, gracze poprzez rozgrywkę są w stanie doświadczyć wyzwań, problemów, cierpień oraz oczywiście podejmowania decyzji z przestrzeni „swojego bezpiecznego fotela". Wszystko w formie kontrolowanej, ale jednocześnie immersyjnej, relaksującej, jednak wymagającej uwagi. Dodając takie spojrzenie na sprawę, z jeszcze większą pewnością można nazwać grę treningiem. Gracz ma okazję "musnąć" istoty decyzji, nie ponosząc jej konsekwencji osobiście. W pewnym sensie „muśnięcie" to jest symbolicznym powołaniem do życia potencjału gry. Zacytuję tu Antoniego Kępińskiego:

Świat zewnętrzny jest zmienny, świat własny tj. ciało, jest stały. Wśród zmieniającego się wciąż otoczenia ustrój żywy musi zachować swoje constantia, swoje "prawdy", jeśli za istotę prawdy uważa się jej niezmienność. Własne ciało jest "prawdziwe", a świat otaczający jest „złudą", gdyż cechą złudy jest ustawiczna zmienność. To, czego 
możemy dotknąć, zetknąć z naszym ciałem, nabiera cech prawdziwej rzeczywistości. [...] To, co nie jest w bezpośrednim kontakcie z naszym ciałem, ma zawsze cechy ułudy, abstrakcji, nierzeczywistości (Kępiński 2012: 32).

Uważam, że w pewien sposób można odnieść słowa Kępińskiego do obcowania graczy z grą komputerową. Ta sama w sobie jest fikcją, wspomnianą „złudą”, jednak przez interakcje z graczem, gra oraz jej fragmenty stają się bardziej rzeczywiste, prawdziwe. Rozgrywka oferuje nam wyzwania, oswajamy się z jej mechaniką, fabułą, postaciami. Czy to dlatego gry wydają się dużej liczbie ludzi tak atrakcyjne? Czy dlatego, że sami gracze, kiedy budowa, fabuła i idea gry im odpowiada, czynią ją środowiskiem immersyjnym? Czy przez swoje interakcje z człowiekiem gra urzeczywistnia to, co nierzeczywiste?

Z pewnością wielu zada sobie pytanie, czy gracze świadomie podejmują decyzje podczas rozgrywki. W swoim badaniu próbowałem dowiedzieć się, jakie wybory są dla nich najtrudniejsze i które wywarły głębokie wrażenie. Wielu graczy mówiących od podejmowanych decyzjach w grach wspomina ich wynik. Naturalne jest, że człowiek w życiu codziennym stara się przewidzieć następstwa swoich czynów, słów; w większości sytuacji zdajemy sobie sprawę, że każda czynność pociąga za sobą pewne konsekwencje. Gracze nie raz podkreślali wagę tego aspektu i niejednokrotnie stwierdzali, że najtrudniejsze decyzje to takie, których następstw nie potrafią przewidzieć:

Najtrudniejsze decyzje w grach to te, których konsekwencji nie można przewidzieć, a które mają istotny wpływ na dalszy przebieg fabuły.

Za trudną uznaję decyzję mniejszego zła (gdy oba wybory niosą jakieś szkody) lub trudne do przewidzenia konsekwencje decyzji. Także decyzje wyrywające się spod kontroli po dokonaniu wyboru.

Najtrudniejsze decyzje to takie, kiedy trzeba wybrać między dwiema sprzecznymi stronami (Kenny i Jane w The Walking Dead) albo takie, których konsekwencje nie są jasne.

Jak widać, konsekwencje są istotne i to one często sprawiają, że graczom ciężko zaakceptować rozgrywkę idącą torem „złej” decyzji i sięgają po wirtualno-psychologiczną funkcję obronną jaką jest wczytanie stanu gry do momentu sprzed jej podjęcia. Sami gracze potwierdzają, że często jest to spowodowane konsekwencjami decyzji. Oto niektóre z wypowiedzi argumentujące powrót do wcześniejszego zapisu rozgrywki:

Bezpośrednie konsekwencje były obciążające sumienie mojej postaci :)

Zbyt duże wyrzuty sumienia lub śmierć ulubionej postaci jako konsekwencja.

Przeważnie jest to chęć sprawdzenia, co oferuje druga ścieżka, z czystej ciekawości. Z rzadka jest tak, że konsekwencje podjętej decyzji bardzo mi nie odpowiadają i wolę już podjąć inną, gorzej pasującą do postaci, byle ich uniknąć. Przykładem niech będą niektóre wybory w zadaniach w serii Baldur's Gate, powodujące odejście jakiejś cenionej postaci z drużyny.

W Planescape: Torment dwa razy: po rozmowie z Ignusem stwierdziłem, że on nie zasługuje na to, by być uwolnionym i powinien dalej się smażyć w ogniu, choć przez to 
traciłem dostęp do potężnych czarów. Innym razem decyzja, która w pierwszej chwili wydawała się słuszna, niosła ze sobą dalece zbyt wielkie konsekwencje - winny poniósł karę niewspółmierną do winy.

Oczywiście decyzje podjęte w grach komputerowych nie mają tej samej siły, co w życiu realnym, w przypadku tragedii ludzie nie mogą "zacząć od nowa” czy „spróbować jeszcze raz”, jednakże nie chodzi tutaj o to, lecz o pokazanie wyników postępowania. Tak jak w grach, tak i w życiu, wiele konsekwencji jest trudnych do przewidzenia.

Warto jednocześnie zauważyć, że pierwsza z wypowiedzi jest nacechowana żartobliwością, co wskazuje na swego rodzaju dystans respondenta/respondentki do własnych słów. Można oczywiście rozumieć to na wiele różnych sposobów.

Jakie są jeszcze podobieństwa między grami a rzeczywistością? Czy sam proces podejmowania decyzji przebiega podobnie jak w życiu codziennym? Jak wygląda kwestia tytułowego sumienia graczy? Oto pytania, którymi pragnę zająć się w dalszej części tekstu, jednocześnie ujawniając to, czym kierują się gracze, podejmując swoje decyzje.

\section{Sumienie i motywacje graczy, czyli co stoi za decyzjami w grach komputerowych}

W poprzedniej części artykułu w dużej mierze piszę o tym, jak można interpretować różne elementy gier, wspominam tytuły i odnoszę się do samego podejścia graczy do podejmowania decyzji w grach komputerowych oraz do ich konsekwencji. To właśnie stosunek graczy do gier komputerowych nadaje wagi całemu dyskursowi. Podczas swoich badań postanowiłem sprawdzić cztery różne aspekty dokonywania wyborów, w poszukiwaniu tego najważniejszego dla graczy. Ich zadaniem było wybrać, jak istotne są poszczególne aspekty, co motywowało ich wybory. To, jak rozłożyły się głosy 171 ankietowanych (wyniki procentowe uwzględnione zostały ważne głosy, czyli tych respondentów, którzy przesłali poprawnie wypełnione formularze), ukazuje tabela $1^{1}$.

Jak widać, najistotniejszy okazał się aspekt moralny, co ukazuje ważne i ciekawe zjawisko, jakim jest uczynienie gry nie tylko miejscem rozrywki, ale również wirtualnym uniwersum, w którym gracz może stworzyć swoje superego, reprezentację moralności, sumienia i możliwości decydowania. Na tej mocy gry komputerowe okazują się przestrzenią wyzwania. Co ciekawe, to właśnie gracze sami ukształtowali tę przestrzeń - wymagają (co wskazałem we wcześniejszych partiach tekstu), by produkcje zawierały znaczącą liczbę możliwości decydowania, chcą decydować o losach swojej postaci i świata, w którym się znajduje, jednocześnie jednak dochodzi do swoistego transferu moralności graczy do fikcyjnego świata gry, przez co staje się on areną, na której dochodzi do walki o poglądy, wątpliwości, problemy moralne. Parząc także na aspekt odgrywania postaci również oceniany jako bardzo istotny - można zastanowić się, czy gracze nie pożądają konfliktu. Jednocześnie wysoko cenią możliwość importu własnej

${ }^{1} \mathrm{~W}$ tabeli ujęto stan na rok 2014. W planach jest kontynuacja badań, zbierania głosów oraz analiza wyników. 
Tabela 1. Aspekty brane pod uwagę przez graczy podczas podejmowania decyzji w fabularnych grach wideo

\begin{tabular}{|c|c|c|c|c|}
\hline & Nieistotny & Mało istotny & Istotny & Bardzo istotny \\
\hline $\begin{array}{c}\text { Aspekt moralny } \\
\text { (według własnej hierarchii ważności) }\end{array}$ & $4,1 \%$ & $13,5 \%$ & $25,1 \%$ & $57,3 \%$ \\
\hline $\begin{array}{c}\text { Aspekt wynagrodzenia } \\
\text { (według nagrody za podjęcie takiej, a nie } \\
\text { innej decyzji) }\end{array}$ & $11,1 \%$ & $36,8 \%$ & $34,5 \%$ & $17,6 \%$ \\
\hline $\begin{array}{c}\text { Aspekt odgrywania postaci } \\
\text { (według tego, jak postąpiłaby odgrywana } \\
\text { postać) }\end{array}$ & $9,4 \%$ & $15,8 \%$ & $24,1 \%$ & $50,9 \%$ \\
\hline $\begin{array}{c}\text { Aspekt zmniejszenia wyzwania } \\
\text { (ułatwienie sobie dalszej rozgrywki) }\end{array}$ & $36,8 \%$ & $35,1 \%$ & $19,9 \%$ & $8,2 \%$ \\
\hline
\end{tabular}

Źródło: Opracowanie własne.

moralności do świata gry oraz możliwość odgrywania danej postaci, co w przypadku konfliktu - niepokrywania się kreacji narzuconej postaci z moralnością gracza - doprowadza w pewnym sensie do dychotomii, walki moralności gracza z konstruktem w postaci nakreślonego przez autorów gry charakteru. Jak widać po wynikach wpisanych w tabeli, aspekt zmniejszenia wyzwania oraz aspekt wynagrodzenia cieszą się najmniejszym powodzeniem.

$\mathrm{Z}$ powodu niewielkiej próby badawczej oraz ograniczenia się do respondentów z Polski ciężko jest odnieść wyniki do społeczności wszystkich graczy. Jednakże godne uwagi jest to, że moralność gracza już teraz wyłania się jako znaczący element rozgrywki tuż obok możliwości odgrywania nakreślonej przez twórców roli. Ukazuje to pewne naukowo ciekawe tendencje.

Moralności wraz z podejmowaniem decyzji trudno nie powiązać z wyrzutami sumienia. Aby zachować jasność rozumienia, czym właściwie jest sumienie, odnieśmy się do jego najbardziej popularnej definicji - tej oferowanej przez Encyklopedię PWN, by następnie przejść do nieco innej formuły:

sumienie, gr. syneídesis, łac. conscientia, pojęcie z zakresu moralistyki, etyki i teologii moralnej (o bardzo szerokim znaczeniu), rozumiane zazwyczaj jako: wewnętrzna instancja orzekania moralnego, indywidualne rozeznanie dobra i zła, zinterioryzowane wartości uznane przez jednostkę, a wyznawane przez grupę społeczną (Encyklopedia PWN 2013a).

Jak powszechnie wiadomo, sumienie ma pomagać rozróżniać dobro od zła, często jest opisywane jako wewnętrzny głos podpowiadający, osądzający, przypominający, jak powinniśmy postępować. Definicja z encyklopedii nawiązuje do wartości zaakceptowanej przez jednostkę - aby sumienie faktycznie posiadało swój klasyczny potencjal, potrzebne jest zgodzenie się z treścią. Podczas swojego życia człowiek obcuje z innymi ludźmi, z grupą społeczną, która na swój sposób rozwija jednostkę. Poprzez opiekunów, wpływ środowiska społecznego charakterystycznego dla danej jednostki dochodzi do przekazu zasad oraz wartości; jednostka zostaje socjalizacyjnie uwarunkowana, nabywa pewne kompetencje, hamowane są niepożądane zachowania i rozwijane są cechy potrzebne do istnienia w grupie. Nie bez powodu Lech Witkowski - za Zygmuntem Freudem - charakteryzuje sumienie $\mathrm{w}$ taki oto sposób: 
[...] Freud „utożsamił poczucie obowiązku z uwewnętrznieniem masy idiosynkratycznych epizodów", związanych z przypadkowymi zdarzeniami, obecnymi nawet przy zakłóceniach pamięci. Sumienie zatem to „pamięć zdarzeń idiosynkratycznych (Witkowski 1993: 237)

Sumienie jest tutaj rozumiane inaczej - jako uwrażliwienie i wyczulenie na pewne sprawy, zachowania, zjawiska właśnie dzięki uwewnętrznionym doświadczeniom. Dzięki zdarzeniom człowiek zdobywa możliwość dokładniejszego rozeznania; zmuszany jest do przeformułowania i nadpisania odczuć. Czy można to odnieść do fabularnych gier komputerowych? Owszem.

Niejednokrotnie wspomniane było, że gry oferują nam szeroki wachlarz historii, postaci, relacji oraz graficznych przedstawień miejsc, konfliktów czy po prostu zdarzeń. Gra tworzy specjalne, zamknięte, wykreowane, wirtualne środowisko czy arenę treningową pozwalającą graczom na doświadczanie quasi-przypadkowych zdarzeń. Quasi-przypadkowych dlatego, że jedynie udają takie - zostały wymyślone oraz zaprogramowane przez twórców, lecz z poziomu odbiorcy gry są nie do przewidzenia. Dlatego właśnie zdarzenia te są zarówno przypadkowe, jak i planowane. Co więcej, skłaniają do refleksji. Czy więc konstrukcja gier fabularnych nie rozwija ludzkiego sposobu myślenia? Czy nie uwrażliwia i nie zmusza do pracy swojej umiejętności osądu?

W badaniu zapytałem graczy o to, czy posiadają wyrzuty sumienia po podjęciu takiej, a nie innej decyzji w grze komputerowej. Wyniki przedstawia wykres 2.

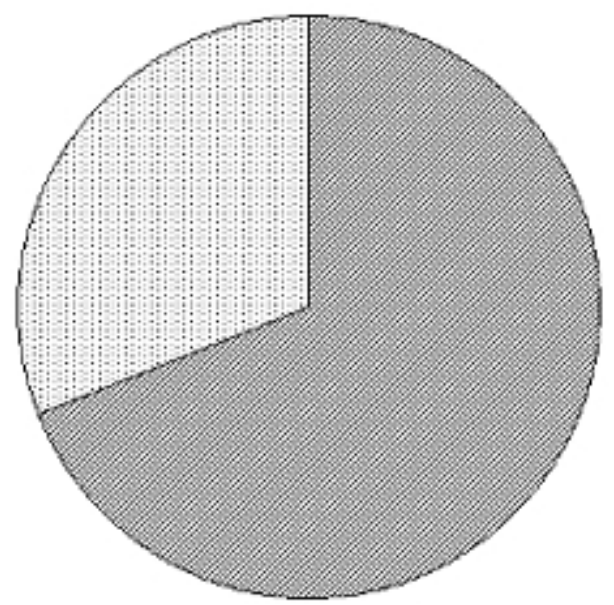

osoby potwierdzające występowanie wyrzutów sumienia we wspomnianej sytuacji $-69 \%$

osoby negujące występowanie wyrzutów sumienia we wspomnianej sytuacji $-31 \%$

Wykres 2. Liczba graczy, u których występują wyrzuty sumienia z powodu "źle" podjętej decyzji w grze komputerowej

Z danych przedstawionych na wykresie wynika, że znacząca liczba graczy odpowiada twierdząco na pytanie o występowanie wyrzutów sumienia z powodu wirtualnych decyzji. Jest to zaskakujący przykład tego, jak fatazmaty, wyobrażenia przenikają do rzeczywistości. Potwierdza to możliwość wpływu świata wyobrażonego na świat realny, codzienny. Mimo że oddziałujące na gracza 
wyobrażenia, grafiki i teksty są osadzone w nierzeczywistym kontekście, to wywołane przez nie emocje, uczucia, wrażenie odpowiedniości podjętej decyzji (lub wręcz przeciwnie) są jak najbardziej prawdziwe. Oczywiście w przypadku gry można uczynić coś, co niemożliwe jest w świecie rzeczywistym - można wczytać wcześniejszy stan gry w celu (jak już wspomniałem) wirtualno-psychologicznej obrony psychicznej; można zmienić swoją decyzję (poza niektórymi przypadkami, kiedy to decyzja i wynik są oddalone na tyle, że wczytanie zaczyna mijać się z celem - dystans czasowy jest w stanie powstrzymać część graczy od użycia starego zapisu gry). O ile powrót do wcześniejszego zapisu gry sprawia, że moment podejmowania decyzji jest mniej znaczący, to jednak pojawienie się wyrzutów sumienia uwrażliwia; jest doświadczeniem. Można iść krok dalej i zapytać, czy gry w ten sposób mogą rozwinąć inteligencję emocjonalną rozumianą jako "zdolność rozumienia i kontroli własnych emocji” (Encyklopedia PWN 2013b). Decyzje - czy to w grach, czy w życiu rzeczywistym - stawiają nas w specyficznych sytuacjach, narzucając reakcję, także emocjonalną. Graczom zostaje rzucone wyzwanie interpretacji odczuć oraz ich kontroli. Czy emocje wywoływane grą faktycznie mają tak wielki potencjał? Trudno odpowiedzieć na to pytanie, jednakże patrząc na to, że potrafią wywołać poczucie winy, wyrzuty sumienia, można zaryzykować odpowiedź, że tak. Kolejne nasuwające się pytanie brzmi: czy ludzie mają potrzebę odczuwania emocji? Nie trzeba długo zastanawiać się nad odpowiedzią, lecz by nie kierować się tylko własnym subiektywizmem, przytoczę słowa psychologa - Daniela Golemana:

[...] kierują nami nasze najgłębsze uczucia, namiętności i pragnienia i jako nasz gatunek zawdzięczamy w znacznej mierze swe istnienie ogromnej roli, jaką odgrywają one we wszystkich ludzkich sprawach. Potęga ich jest niezmierna (Goleman 2007a: 24).

Uczucia i emocje odgrywają znaczącą rolę w rozwoju nie tylko sztuki, ale i całej ludzkości. Czy to właśnie ta potrzeba odczuwania doprowadziła do uwzględnienia emocji i wyzwań (które także stymulują emocje) w grach komputerowych? Potrzeba dreszczyku, wzruszenia, gniewu, miłości, smutku? Chyba można tak twierdzić. Często wspomina się o brutalności w grach komputerowych, o tym, że dają możliwość przejścia rozgrywki w sposób agresywny. Uwzględnia to pewną potrzebę wyładowania, przeżycia „brutalnego katharsis” - wyrzucenia z siebie swoich frustracji, złości, niezadowolenia. Bez potrzeby nie powstałaby taka możliwość. Jednakże dla równowagi wiele gier - zwłaszcza tych z gatunku cRPG uwzględnia wątki miłosne. W seriach Baldur's Gate, Mass Effect, Dragon Age, Neverwinter Nights znajdziemy romanse (kiedyś głównie heteroseksualne, obecnie także homo- i biseksualne) - specjalne, romantyczne ścieżki dialogowe dostępne dla gracza, możliwość rozwoju relacji miłosnej z jedną ze stworzonych przez twórców postaci. Jak pokazuje badanie, romanse także stały się ważnym elementem gier tego gatunku i również one mają potencjał obudzenia wyrzutów sumienia. Jedna z badanych - zapytana o najczęstsze powody wczytania stanu gry - wspomina:

Nie byłam zadowolona z efektu, jaki pociągnęła za sobą decyzja (np. DA - wybieranie Alistaira na króla, a on zrywa z moją postacią ;D). 
Oczywiście wypowiedź ma charakter żartobliwy, jednak podkreśla to, że same romanse są brane pod uwagę, są pamiętane przez graczy. Także uważane są za istotne przez samych twórców. Podczas kampanii reklamowo-teaserowej Dragon Age: Inquisition bardzo często podejmowano tematykę romansów w nowej części popularnej serii. Próba budowy wirtualnej relacji także jest swojego rodzaju wyborem - dialogi są serią linijek tekstu, to gracz wybiera, co chce powiedzieć postaci, z którą prowadzi romans. Nie chodzi jedynie o to, bo postacie mają swój określony charakter, nakreśloną przeszłość, tak więc w trakcie gry odnoszą się z aprobatą bądź dezaprobatą do podejmowanych przez gracza decyzji, a oni sami albo muszą liczyć się z konsekwencją wyboru, albo pamiętać o tym, z kim podróżują (z jakimi postaciami wykonują zadania) i wybierać odpowiedzi zgodne z przekonaniami towarzyszy - co swoją drogą jest ciekawym symulatorem empatii, bo gracz musi pamiętać o tym, kim dana postać jest, jaka jest jej przeszłość i dzięki temu przewidzieć reakcje na decyzje.

Poza romansami, w grach spotkamy związki romantyczne nakreślone całkowicie przez twórców: Corvo i Cesarzowa (Dishonored), Alan i Alice (Alan Wake), czy Sarah i Kaim (Lost Odyssey). Innym typem są postaci, w budowie których emocje, doznania i zrozumienie są kluczowe. Tutaj przykładem może być Nie-Sława ze znanej gry Planescape: Torment.

Rozwój psychologiczny, inteligencja emocjonalna wiążą się z kompetencjami społecznymi oraz funkcjonowaniem. Jak zauważa Goleman we wstępie do swojej kolejnej książki,

Nasze interakcje społeczne działają jak modulatory, pełniąc jakby rolę interpersonalnych termostatów, które wciąż ustawiają na nowo kluczowe aspekty funkcjonowania mózgu, kierując naszymi emocjami. Wynikające stąd uczucia mają dalekosiężne konsekwencje, które ogarniają cały nasz organizm, uruchamiają kaskady hormonów regulujące działanie układów biologicznych, od sercowo-naczyniowego poczynając, na komórkach odpornościowych kończąc. [...] A zatem związki z innymi osobami kształtują w zadziwiającym stopniu nie tylko nasze doświadczenia, ale również biologię organizmu (Goleman 2007b: 11).

Później autor wspomina, że relacje z innym ludźmi mogą mieć zarówno dobry, jak i zły wpływ. Oczywiście gry nie zastąpią związków z prawdziwego życia, ale przez ukazanie nam wirtualnych konstruktów możemy analizować, odgrywać rolę, poznawać punkty widzenia - w ręce gracza zostaje przekazany prawdziwy symulator, który także może zaciekawić, zmusić do refleksji, radości, złości, gniewu, zamyślenia.

W ten sposób ujawnia się cały potencjał - podejmowania decyzji, ich powiązań z sumieniem, potrzeba emocjonalności, która jednocześnie przenika się z inteligencją społeczną. Graczom nie jest obojętne to, co oferują gry. Chcą słuchać historii, symulować życie. Dużo ludzi odpowie, że nie jest to prawdziwe życie, więc nie jest wartościowe, jednakże, jak starałem się pokazać, to, co wywołują gry, przenosi się do świata rzeczywistego. Czyż innym przykładem rozwoju człowieka nie są książki, które posiadają tę samą immersyjność, potencjał opowiadania, nawiązywania do rzeczywistości, nauki, odprężenia czytelnika, zaciekawienia, rozwoju. Jak wspomina jeden z respondentów, 
Gry są chyba jedynym medium, które umożliwia nam nabycie życiowego doświadczenia bez ponoszenia ich negatywnych skutków w naszym prawdziwym życiu. Mają potencjał być jak Planescape'owe sensoria, który rzadko kiedy jest wykorzystywany.

Poniżej krótkie wyjaśnienie, czym jest sensorium we wspomnianej grze:

Przewodnik po doznaniach: Mężczyzna przytakuje. „To publiczne sensorium, w którego pomieszczeniach mieszczą się kamienie doznań. Każdy z nich zawiera jakieś doznanie - albo zestaw doznań - którego może doświadczyć ten, kto go użyje. Czuciowcy mogą korzystać z nich bez żadnych ograniczeń, a pozostali muszą uiścić małą opłatę. Czy taka odpowiedź zaspokoiła twoją ciekawość?"

Pani Thorncombe: Kamienie doznań zapewniają mi wszystko, czego moje pokaźne bogactwo kupić nie zdoła. [...] Każdy kamień ma w sobie zapisane takie czy inne doświadczenie. Kiedy po raz pierwszy przybyłam do tego gmachu, spędziłam z nimi niewiele czasu. Dopiero teraz uświadomiłam sobie ile straciłam. [...] Czemu miałabym tracić czas [...] kiedy mogę zostać tu, wśród tych drogocennych kamieni, każdego dnia przeżywając sto nowych bytów? (Planescape: Torment 1999)

Cytowane fragmenty pochodzą z linii dialogowych Planescape: Torment, postanowiłem potraktować grę jak książkę, ponieważ gry także są tekstem.

Sensoria, tak jak gry, oferują przeżycia, pozwalają dostarczać wrażeń. Potrafią uzależnić jak literatura, ale wykorzystane w odpowiedni sposób opowiedzą historię i podarują doświadczenia, uchwycą metodą wirtualnej impresji fabułę, pozwolą do niej wrócić, przeczytać dialogi ponownie. Pozwalają na „przeżycie stu nowych bytów", a właśnie na doświadczaniu czegoś więcej niż realnego świata opiera się ludzka egzystencja. Od prehistorii ludzie słuchali opowieści, przedstawiali je na jaskiniach w Lascaux; później czytali; zaczęli historie i powieści oglądać na ekranie, by w końcu przeżywać je także wirtualnie. Oczywiście to nie jedyne sposoby odczytywania znaczeń - bo fikcja właśnie tym jest, odczytywaniem znaczeń - można nawiązać do historii ukrytych w fotografiach, obrazach, czy nawet muzyce. Po cytowanej wypowiedzi można zauważyć, że gracze sami czasami zauważają, że gry opowiadają, dają doświadczenia. Prawdę mówiąc, graczy najlepiej pytać o to, jak odbierają gry, czemu decyzje w grach są dla nich ważne, jakie są ich domysły odnośnie gier:

Gry zmuszające do podejmowania trudnych decyzji są dojrzalsze, mogą skłonić do refleksji, są też argumentem przeciwko twierdzeniu, że gry są rozrywką prymitywną i bezmyślną.

Gry mogą nie tylko zapewniać rozrywkę, ale i uczyć, jeśli młodzi stażem gracze wcześnie zaczną podejmować ważne decyzje (w grach oczywiście), może to się odbić w ich życiu, może łatwiej będzie im podejmować logiczniejsze i lepsze decyzje.

[...] to sprawia, że rozwijamy się jako osoby i w bezpiecznych warunkach testujemy naszą moralność. Możemy lepiej poznać siebie i wystawić na próbę nasz kodeks moralny.

Przez możliwość wczytania poprzedniego zapisu gry można zawsze sprawdzić, "co by było, gdyby...", jedynie trzeba pamiętać, że taka możliwość jest tylko w grach, a w życiu rzadko można zacząć wszystko od początku. 
Postanowiłem przytoczyć różne wypowiedzi, dać graczom możliwość wypowiedzenia się o grach i ich odczuciach. Przez sam fakt wagi, jaką wiążą z grami ludzie - z różnych środowisk, w różnym wieku, różnego światopoglądu - warto przyjrzeć się temu pedagogicznie. Zwłaszcza w kontekście zarzutów względem gier komputerowych, bo i takie się pojawiają, jak chociażby wypowiedź:

Decyzje w grach to iluzja wyboru starająca się zamaskować niedojrzałość medium.

Tekst ten nie powstał, aby sakralizować gry komputerowe, dlatego dużą wagę powinno się przyłożyć do spojrzeń krytycznych, bo właśnie one potrafią przebudzić wątpliwości, które stać się mogą impulsem do dalszego działania. Można uznać to za swojego rodzaju próbę falsyfikacji, zwątpienia w postawione pytanie o potencjał fabularnych gier komputerowych.

$\mathrm{W}$ naukach społecznych pożądane jest wątpienie w teorię, w postawione hipotezy - wątpliwości wymuszają dalsze badania, które są niezbędne zwłaszcza w przypadku gier komputerowych w kontekście pedagogicznym. O ile czasami bada się je w ramach innych gałęzi nauk społecznych, to wciąż są bardzo słabo reprezentowane na poziomie edukacji, socjalizacji, interakcji z dziećmi, młodzieżą czy dorosłymi.

\section{Edukacyjne zastosowanie fabularnych gier komputerowych - w poszukiwaniu dalszych potencjałów}

Poszukując możliwych zastosowań fabularnych gier komputerowych, postanowiłem zapytać graczy o ich edukacyjny potencjał, jako że niemożliwe jest, by przy wielogodzinnej grze w tygodniu gracze nie uczyli się czegoś nowego. Można to porównać do przechodzenia dodatkowych, wirtualnych kursów - pytanie w czym?

Otrzymane odpowiedzi ujawniły opinie graczy na ten temat i w tej, przedostatniej części tekstu dokonam przeglądu i analizy wybranych spostrzeżeń oraz tez graczy. Postaram się rozważyć część z nich w kontekście pedagogicznym, a zacząć pragnę o tejże wypowiedzi:

Konieczność ponoszenia konsekwencji swoich decyzji podejmowanych w świecie wirtualnym może uczyć odpowiedzialności i oduczać pochopności w dokonywaniu wyborów w życiu. Może też uświadamiać, że nie zawsze da się zadecydować prawidłowo i tym samym pomagać w uporaniu się z poczuciem winy i rozczarowania w momencie, gdy nie uda nam się przewidzieć skutków decyzji i ostatecznie wybierzemy źle. Dobrze by jeszcze było, gdyby rodzice nie zapomnieli uświadomić dzieci, że w realu nie ma save'ów ani respawnu...

Już wyżej wspomniałem, że każda gra (w różnym stopniu) ma potencjał ukazania wagi decyzji - tak, jak w efekcie domina, prowadzą one do kolejnych zdarzeń i wypadków. Potencjał ten pozostaje poważnie zmniejszony przez możliwość powrotu do wcześniejszego momentu rozgrywki, lecz nie w przypadku każdej gry. Jest to kwestia jej zakodowania, jako że już obecnie istnieją gry, w których konsekwencje decyzji pojawiają się nie zaraz po jej podjęciu, ale dużo 
później, co zniechęca graczy do ponownego rozegrania pewnej sekwencji i nakłania do pogodzenia się ze swoim wyborem oraz zachęca do ponownego zagrania i poznania fabuły "od drugiej strony”.

Pojawia się też ważna kwestia różnicy pomiędzy życiem rzeczywistym a wirtualnym - czy należy uświadamiać ludziom, zwłaszcza dzieciom, że w przypadku życia codziennego nie ma i nie będzie możliwości „wczytania” i zdecydowania jeszcze raz? Ludzie zawsze chcą dążyć do realizacji idealnego ja. Dochodzi do naśladownictwa, tak samo jak w przypadku filmów, książek i innych inspirujących tekstów. Procedura zachowań powinna zostać jednak taka sama, skupiać się na samoświadomości. Nie uważam, by gry domagały się specjalnego wyróżnienia jeżeli chodzi o nakłanianie do niebezpiecznych zachowań. To samo można powiedzieć o śmiałkach z innych medialnych kreacji, jednocześnie trudno stwierdzić, że telewizja jest zła sama w sobie jedynie dlatego, że niektórzy mogą posunąć się do naśladownictwa niebezpiecznych zachowań oraz efektów związanych z przecenieniem własnych możliwości. Jednak czy można całkowicie zapomnieć o samej możliwości takiego zachowania? Nie - tak jak w przypadku książek, filmów, komiksów, opowieści itp.

Wspomniałem, że gry komputerowe mają taką samą możliwość inspirowania, jak inne produkty kultury. Jedna z zapytanych osób zauważa:

Gra prosta, pozbawiona konieczności podejmowania decyzji, ciągnąca nas prosto jak po sznurku, nie da nam możliwości zastanowienia się nad innymi opcjami rozwoju akcji w inną stronę. Aspekt „co by było gdyby” pobudza wyobraźnię i zmusza do myślenia.

Po pierwsze, samo inspirowanie do spekulowania rozwija wyobraźnię, możliwość tworzenia alternatywnej ścieżki zdarzeń, przewidywania czy łączenia poszczególnych zdarzeń w łańcuchy przyczynowo-skutkowe. Jest to niezwykle przydatna umiejętność usprawniająca postrzeganie powiązań między czynnościami, zachowaniami, pytaniami i odpowiedziami. Poszedłbym jednak w analizie tegoż potencjału dalej, bo w stronę rozwoju literackiego. Na pytaniu „co by było gdyby" tworzone są opowiadania gatunku fanfic - teksty opowiadające o przygodach postaci między innymi z gier ${ }^{2}$. Autorzy gatunku umieszczają swoje ulubione postacie w nowych rolach, nowych przygodach, nowych miejscach czy sytuacjach. Dzięki zdobytej inspiracji, młodzi amatorzy tworzą teksty dla siebie i innych, co prowadzi do rozwoju zdolności literacko-językowych. Przykładem portalu z opowiadaniami fanfic opartymi na motywach i postaciach z gier jest strona FanFiction (www.fanfiction.net/game), na której znajdziemy ponad kilkadziesiąt tysięcy opowiadań.

Nawiązując do dalszych wypowiedzi, można doszukać się w grach możliwości obrazowania tego, co rzeczywiste:

Przede wszystkim gra video nadaje się świetnie do zobrazowania różnych niebanalnych konfliktów (np. politycznych, społecznych) i zgłębienia się w nie właśnie poprzez podejmowanie decyzji. Moim zdaniem pozwoli to na lepsze ich zrozumienie, niż w wypadku tylko posłuchania/przeczytania racji stron.

${ }^{2}$ W szerszym znaczeniu opowiadania tworzone przez fanów, skupiające się na miejscach, historiach i wydarzeniach z ulubionych gier, filmów, seriali, książek itd. 
Także gry fabularne nie tylko mogą zainspirować do tworzenia nowej fikcji, ale także zachęcić do zrozumienia rzeczywistości. Gra jest fikcją, która udaje rzeczywistość. Może pod pozorną nierealnością pokazać realne konflikty. Niektóre z nazw, również aktorzy zdarzeń, zmienią się, jednakże idee często pozostają te same. Gry ukazują idee wojny, miłości, zdrady, tajemnicy, przygody oraz wiele innych. Oczywiście, na ile będą one prawdziwe, zależy od twórców, dlatego nie po raz pierwszy zaznaczę tutaj istotność pisarzy i deweloperów, przed którymi stoi trudne zadanie - zarówno artystycznie, jak i moralnie i marketingowo.

Co ciekawe, wielu graczu zauważa, że poprzez gry dochodzi do wzrostu świadomości oraz że pomagają zrozumieć samego siebie:

[...] Ludzie bardziej wrażliwi będą mieli okazję, aby zastanowić się nad własnymi reakcjami i motywacjami.

Odbiorcy, stawiając się w sytuacjach fikcyjnych, mogą symulować własną osobę w okolicznościach, które dotychczas faktycznie nie zaistniały w ich życiu realnym. Gracz musi zapytać siebie, jak zachował(a)by się w rzeczywistości. Poprzez to pytanie dochodzi do wzrostu świadomości, ale wyzwania takie wspomagają także wykrystalizowanie się w człowieku konkretnych zasad - o ile gracz jest w stanie dojść do odpowiedzi na pytanie, czemu właściwie postąpił(a) w taki, a nie inny sposób.

Oczywiście podane powyżej cytaty i interpretacje są jedynie jednostkowymi głosami, ale głosy te należą do graczy - osób obcujących z grami. Wypowiadając się o grach w ten sposób, bazują na własnym doświadczeniu lub pragnieniu ukazującym, jakie powinny być gry, jakie cechy powinny posiadać. Pojawiło się także wiele odpowiedzi negujących posiadanie przez gry jakichkolwiek wartości edukacyjnych i także tę informację należy zaznaczyć.

\section{Zakończenie}

Powyższy artykuł ma dość nietypowe zadanie - nie wyjaśnienia czy rozstrzygnięcia pytania o to, jakie są gry komputerowe, jaki niosą za sobą potencjał, jacy są gracze, czy jakie są ich oczekiwania względem gier. Gry istnieją, pojawiają się coraz to nowi gracze; gry opowiadają historie - czasami nowe, czasami stare, lecz $\mathrm{w}$ nowej formie. Wszystkie $\mathrm{z}$ tych historii opowiedziane są przez twórców gier, którzy odbiorcom całkowicie - lub przynajmniej częściowo - narzucają pewne interpretacje, zachowania, idee. Wiele gier fabularnych daje możliwość w jakimś stopniu podejmowania decyzji. Wszystko to składa się na procesy socjalizacyjne przekazywane są treści kulturowe, zostają one zobrazowane; dochodzi do podejmowania decyzji, kształtowania kompetencji odbioru, obcowania z rzeczywistością wirtualną itd.

Czy w tym wszystkim jest miejsce na uwrażliwienie? Na dotknięcie tematów uniwersalnych? Owszem, bo gry - tak jak książki, filmy, opowieści w innych formach - w większości przypadków bazują na archetypach oraz na zabawie nimi. 
Artykuł ten ma także jeszcze jedno, niezwykle istotne zadanie: ma on pomóc nakreślić nowe pytania o potencjał gier, ich funkcje i przyszłość w edukacji nieformalnej. Gry komputerowe wciąż są niewiadomą w kontekście pedagogiki przez małe zainteresowanie pedagogów tą tematyką, podczas jednoczesnego niezaprzeczania dużego wymiaru czasowego spędzanego przez dzieci, młodzież, młodych (i nie tylko) dorosłych na interakcji z tymże medium. Gry są tekstem kulturowym, operują treściami, znakami, symbolami - wszystkim zaczerpniętym z kultury. Gry są światem fikcyjnym przechodzącym w rzeczywistość poprzez współdziałanie z graczem, poprzez wzbudzanie emocji, czy nawet tytułowych wyrzutów sumienia. Czy można więc zaprzeczyć istotności medium, które potrafi poprzez światy wyobrażone wpływać na to, co codzienne i realne?

\section{Literatura:}

Bauman Z., May T., 2004, Socjologia, Poznań: Wydawnictwo Zysk i S-ka.

Encyklopedia PWN, 2013a, hasło: sumienie, http://encyklopedia.pwn.pl/haslo/sumienie;3981316.html [dostęp: 2.12.2013].

Encyklopedia PWN, 2013b, hasło: Inteligencja emocjonalna, http://encyklopedia.pwn.pl/haslo/ inteligencja-emocjonalna;3915045.html, [dostęp: 2.12.2013].

Fanfiction, 2013, www.fanfiction.net/game/ [dostęp: 6.12.2013].

Filiciak M., 2006, Wirtualny plac zabaw. Gry sieciowe i przemiany kultury wspótczesnej, Warszawa: Wydawnictwa Akademickie i Profesjonalne.

GIT: Kids 2014, http://2014.gitkids.pl/raport [dostęp: 28.05.2014].

Goleman D., 2007a, Inteligencja emocjonalna, tłum. A. Jankowski, Poznań: Wydawnictwo Media Rodzina.

Goleman D., 2007b, Inteligencja społeczna, tłum. A. Jankowski, Poznań: Dom Wydawniczy Rebis.

Kępiński A., 2012, Lęk, Kraków: Wydawnictwo Literackie.

Kruszelnicki M., 2010, Oblicza strachu. Tradycja i wspótczesność horroru literackiego, Toruń: Wydawnictwo Adam Marszałek.

Olejniczak P., 2012, Wirtualny Teatr. Koncepcje Ervinga Goffmana w świecie gier sieciowych [w:] Pomiędzy realnościq a wirtualnościq. Internet $i$ nowe technologie $w \dot{z} y c i u$ codziennym, red. A. Kuczyńska, K. Stachura, Gdańsk-Warszawa: Warsztaty Analiz Socjologicznych, Fundacja Ośrodek Badań i Analiz Społecznych, http://www.obias.pl/publikacja-pomiedzy-realnoscia-i-wirtualnoscia [dostęp: 4.01.2014].

Planescape: Torment, 1999, Black Isle Studios, Interplay Entertainment, CD Projekt (polski dystrybutor).

Porczyński D., 2013, Komputerowe gry fabularne - pogranicze światów rzeczywistego i wirtualnego, "Zeszyty Naukowe Politechniki Śląskiej” z. 65.

Szeja J.Z., 2004, Gry fabularne - nowe zjawisko kultury wspótczesnej, Kraków: Wydawnictwo Rabid.

Witkowski L., 1993, Homo Idiosincraticus. Richard Rorty czyli spór o (po)wage ironii, „Poznańskie Studia z Filozofii Nauki" t. 13.

Zimbardo P., 2008, Efekt Lucyfera, Warszawa: PWN. 


\section{Summary}

Gamers' Remorse: Decision Making in Story-oriented Video Games in the Context of Socialization and Social Awareness

Aim of this article is to analyze the potential of video games in the context of socialization and social sensitivity and awareness towards marginalized topics or those considered a taboo. My analysis and conclusions are based on research of video-games players, their opinions and thoughts about this unique medium. I am mostly interested in effect of remorse caused by some decisions in video games and the effect of immersion that allows players to gain real experience through fiction. This text is also to show video games in "non-alarmist light" and describe (often omitted in pedagogy) different interaction between gamers (children/teenagers/adults) with video games.

Keywords

video games, games studies, pedagogy, socialization, new media

\section{Słowa kluczowe}

gry wideo, game studies, pedagogika, socjalizacja, nowe media 